\title{
Distinct age and landscape influence on two reservoirs under the same climate
}

\author{
A. M. Geraldes ${ }^{1} \&$ M. J. Boavida ${ }^{2, *}$ \\ ${ }^{1}$ Escola Superior Agrária, Instituto Politécnico de Bragança, Portugal \\ E-mail: geraldes@ipb.pt \\ ${ }^{2}$ Centro de Biologia Ambiental, Departamento de Biologia Animal, Faculdade de Ciências da Universidade \\ de Lisboa, Campo Grande C2, 1749-016 Lisboa, Portugal \\ E-mail: zboavida@fc.ul.pt \\ (*Author for correspondence)
}

Key words: trophic state, nutrient sources, land use, reservoir age, water quality, socio-economic influence

\begin{abstract}
With the purpose of finding out whether different landscape occupation could affect water quality in two reservoirs of distinct age and subjected to the same climatic influence, several factors were investigated in a study lasting from January 2000 till December 2001. Total phosphorus, orthophosphate, chlorophyll $a$ concentrations and water colour were determined monthly in winter and biweekly in summer, in two reservoirs located in the Portuguese part of River Douro catchment. Complementarily, variables such as nitrate, ammonium ion and ammonia gas, as well as water temperature, dissolved oxygen, conductivity, and transparency were measured. Trophic state of both reservoirs was assessed by computation of Carlson's Trophic State Index. The potential allochthonous sources of phosphorus and nitrogen to both reservoirs were identified and estimated. Differences between reservoirs were found for conductivity, water temperature, transparency and water colour. According to Carlson's Trophic State Index both reservoirs were classified as meso-eutrophic from winter to the beginning of summer, and as eutrophic from this period onwards. Intrinsic factors such as age of reservoir, organic matter inputs from decomposition of flooded terrestrial vegetation and exposure of littoral sediments to cycles of drying and wetting, as well as extrinsic factors such as grazing and frequent land fires, can explain the trophic state of S. Serrada Reservoir. Allochthonous sources of nutrients originated from agriculture and grazing in the catchment area, and recreational activities in the reservoir probably are the factors with greatest influence on Azibo Reservoir trophic state. Based upon the obtained data, management measures are suggested to prevent further eutrophication and water quality degradation in both reservoirs.
\end{abstract}

\section{Introduction}

In climates characterised by irregular precipitation regime such as in Portugal, freshwater resources are scarce. Therefore, reservoirs can provide a large amount of water for agricultural and urban supply, as well as energy generation, fishing and recreational purposes. Watershed geology, climate, soil, land slope and intrinsic factors such as age of the reservoirs, water level fluctuations, morphometry and water residence time may have a significant effect on water quality and trophic state of those freshwater systems (Harper, 1992; Wetzel, 2001). Pressure caused by human activities in the catchment area and reservoir vicinity generally leads to an intensification of surface runoff, causing an increase in eutrophication, thus threatening water quality. Runoff rates depend mainly on land use, vegetation cover and landscape mosaic (Johnes et al., 1996; Rybak, 2000; Hallissey et al., 2001; Szyper \& Gołdyn, 2002).

The present study was carried out for two years on two reservoirs located at the Portuguese part of the international Douro catchment basin, in Trás-osMontes region (NE Portugal). Serra Serrada Reservoir was filled for the first time in 1995 and, in spite of its importance for urban water supply, it has never 
been studied. Azibo Reservoir was created in 1982. A preliminary study on main nutrient concentrations and on trophic state was undertaken in 1987/1988 (Vasconcelos, 1990); so far, this was the only limnological study on Azibo. Therefore, the purpose of the present research was to find out whether age and different landscape occupation and use of the water (causing distinct water level fluctuations) could affect water quality in the reservoirs. This was achieved through: (1) determining total phosphorus, orthophosphate and chlorophyll $a$ concentrations and water colour; complementarily, measuring nitrate, ammonium ion and ammonia gas, as well as water temperature, dissolved oxygen, conductivity and transparency; (2) assessing reservoir trophic state by calculating Carlson's Trophic State Index (Carlson, 1977); (3) identifying and estimating the potential allochthonous sources of phosphorus and nitrogen which might contribute to explain reservoirs trophic state.

\section{Study area}

Location, as well as morphological and hydrological characteristics of both reservoirs, are shown in Figure 1 and Table 1, respectively. The climate in this region is continental, with warm, dry summers and long, cold winters. However, because of the influence of Mediterranean climate in the Iberian Peninsula, precipitation and temperature vary greatly over the year. Summer is the dry season and can last for 3-5 months. Precipitation regime is also very irregular, with wet winters followed by dry ones (Fig. 2).

Serra Serrada (S. Serrada) Reservoir is located in the mountainous system of Montesinho Natural Park. It was built to supply water to the city of Bragança (34750 inhabitants, INE 2001) and to generate hydroelectric power. Consequently, pronounced water level fluctuations occur, ranging between 8 and 10 $\mathrm{m}$. Thermal stratification was observed from June to August in 2000 and from June to September in 2001. Disruption of stratification was coincidental with the lowest water level. The surrounding vegetation is composed of scrubs of Erica spp., Genista spp., Chamaespartium sp. and Salix spp..

Azibo Reservoir was built for water supply and irrigation, but those uses are not significant and the reservoir is utilised mainly for recreation. In spite of being fed by three small streams, which can dry in summer, water level fluctuations in this reservoir are not very accentuated, varying between 1.5 and $2 \mathrm{~m}$.
Thermal stratification occurred from June to October in both years of study. The surrounding vegetation is composed of Quercus suber, Quercus pyrenaica, Quercus faginea, Quercus rotundifolia, Genista spp., Cistus ladanifer, Salix spp., Fraxinus angustifolia and Populus spp..

Direct human influence on S. Serrada impoundment is considered negligible. There are no villages, there has been no agricultural activity for approximately 20 years, and recreational activities are not significant. However, grazing can be very intense in the catchment basin during summer months. For most of the year there are only about 200 sheep grazing in the S. Serrada catchment, yet from May to August about 5000 sheep from lowlands are transported from the surrounding lowlands to graze in the catchment and reservoir surroundings. Consequently, this area is very often subjected to wild fires that are mainly induced by shepherds to obtain better graze. In Azibo direct influence of human activities is greater during summer when about 10000 people use reservoir and surroundings for recreation such as swimming, camping and boating. Angling is also an important activity. According to Sampaio (pers. com.) this activity is performed by about 1000 people. The watershed area is occupied by meadows (1286 ha), woodland and scrub (935 ha) and extensive agriculture (2235 ha). The latter is found all over the year and the main crops are olives (657 ha), chestnuts (650 ha), cereals (546 ha), vineyards (144 ha) and potato (85 ha). In the reservoir shore there are intensive crops, which are less than $1 \%$ of all crops (INE, 1999). Extensive grazing also occurs in this drainage basin. According to INE (1999), there are 5766 sheep and goats, 494 cattle and 531 pigs. In Azibo catchment area there are several small villages. The total of inhabitants is about 1500 and most of them are more than 50 years old (INE, 2001). Passing nearby and over the streams that feed this reservoir there is a highway, IP4. In this highway average daily traffic volume is 6000 vehicles (Barbosa \& HvitvedJacobsen, 1999). There is no industrial activity in both reservoir catchments.

\section{Methods}

\section{Water parameters}

Water samples were collected monthly in winter and biweekly in summer, from January 2000 to December 2001 in both reservoirs. In both cases there was one 

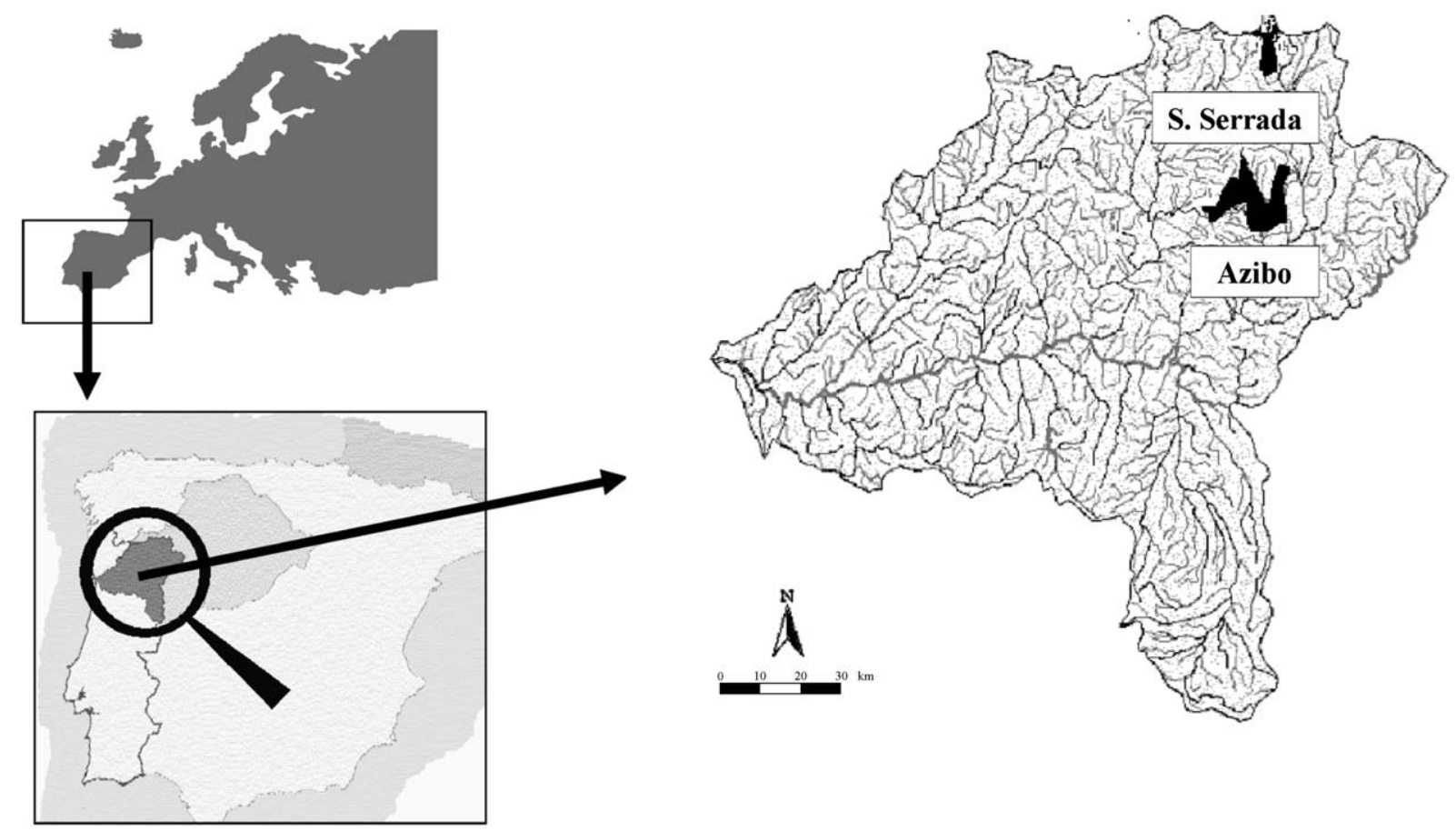

Fig. 1. Location of S. Serrada and Azibo reservoirs.

Table 1. Main general features of S. Serrada and Azibo reservoirs

\begin{tabular}{lcc}
\hline & S. Serrada & Azibo \\
\hline Location & Latitude: $41^{\circ} 57^{\prime} 12^{\prime \prime}(\mathrm{N})$ & Latitude: $41^{\circ} 32^{\prime} 50^{\prime \prime}(\mathrm{N})$ \\
& Longitude: $6^{\circ} 46^{\prime} 44^{\prime \prime}(\mathrm{W})$ & Longitude: $6^{\circ} 53^{\prime} 38^{\prime \prime}(\mathrm{W})$ \\
Altitude $(\mathrm{m})$ & 1300 & 500 \\
Geology & Granitic bedrock & Schistic bedrock \\
Mean annual precipitation $(\mathrm{mm})$ & 1300 & $800-1000$ \\
Mean annual air temperature $\left({ }^{\circ} \mathrm{C}\right)$ & $<8.0$ & $12.5-14.0$ \\
Watershed area $\left(\mathrm{km}^{2}\right)$ & 6.7 & 89.0 \\
Reservoir area $\left(\mathrm{km}^{2}\right)$ & 0.25 & 4.10 \\
Total capacity $\left(\mathrm{m}^{3}\right)$ & $1680 \times 10^{3}$ & $54470 \times 10^{3}$ \\
Maximum depth $(\mathrm{m})$ & 18 & 30 \\
Mean depth $(\mathrm{m})$ & 6.72 & 13.2 \\
Water residence time (years) & 0.36 & 2.22 \\
Year of filling & 1995 & 1982 \\
\hline
\end{tabular}

single sampling station, located at maximum depth. Water samples were obtained from the upper 30-40 $\mathrm{cm}$ stratum directly into acid-rinsed bottles and were transported to the laboratory in a cold container. Soluble reactive phosphorus (SRP) was estimated by the method of Murphy \& Riley (1962) and total phosphorus (TP) concentrations were assessed after acid hydrolysis with persulfate for $60 \mathrm{~min}$ under high tem- perature and pressure. Chlorophyll $a$ (CHL $a$ ) was obtained from a sample of $500-1000 \mathrm{ml}$ of water filtered through a Whatman GF/A filter no more than $2 \mathrm{~h}$ after collection. Concentrations were determined spectrophotometrically after overnight extraction in $90 \%$ acetone. Water colour was determined according to the Cuthbert \& Giorgio (1992) method. Physical factors such as water temperature, dissolved oxygen, 

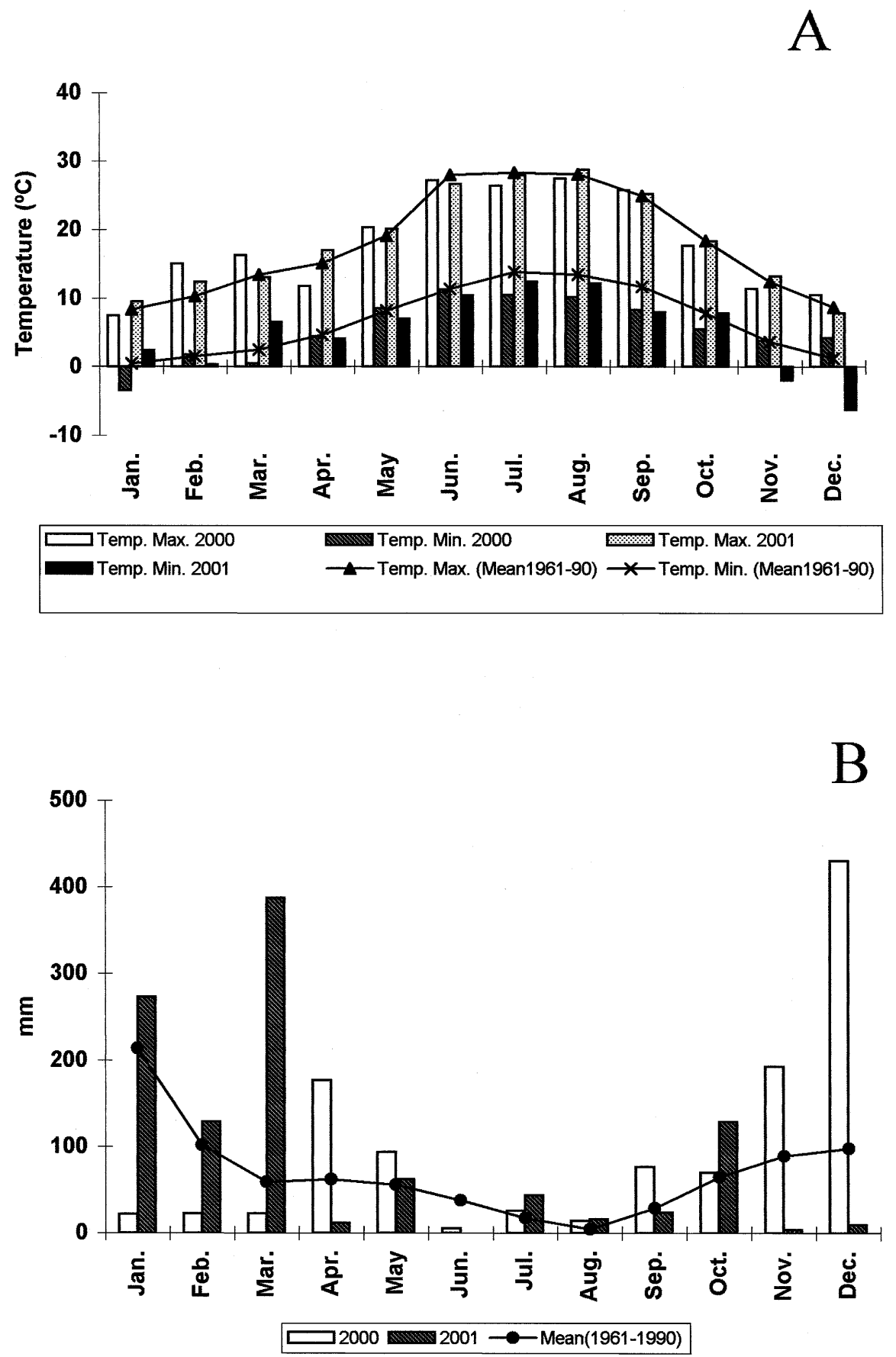

Fig. 2. Temperature (A) and precipitation (B) during the period of study in Bragança, the main city closest to both reservoirs (source: Agroclima Lab- ESAB) and mean values of those variables observed between 1961 and 1990 (source: IM, Institute of Meteorology). 
conductivity, $\mathrm{pH}$, as well as nitrate $\left(\mathrm{N}-\mathrm{NO}_{3}\right)$, ammonium ion $\left(\mathrm{N}-\mathrm{NH}_{4}\right)$ and ammonia gas $\left(\mathrm{N}-\mathrm{NH}_{3}\right)$ were measured in situ with a 6820 YSI Multiparameter Water Quality Monitor. Water transparency was determined as Secchi disk depth $(20 \mathrm{~cm}$ diameter black and white disk). Carlson's Trophic State Index (TSI) (Carlson, 1977) was computed from Secchi disk transparency (TSI (SD)), TP concentrations (TSI (TP)) and CHL $a$ concentrations (TSI (CHL)). All three components of the index were taken into account for better interpretation, since in reservoirs inorganic seston is in general much more abundant than organic particles.

Multidimensional Scaling (MDS) was used to identify the differences between studied reservoirs. In this method samples are arranged in a continuum in such a way that those close together are similar and those which are far apart are dissimilar. Euclidean distance was used to measure the dissimilarity between samples. A 'z-scores' transformation was used to standardize the data (Ter Braak, 1995). A Kolmogorov-Smirnov test was performed as a complement to the multivariate analysis mentioned above to assess differences in studied variables between both reservoirs (Sokal \& Rohlf, 1981). All analyses were performed using SPSS 8.0.

\section{Potential allochthonous sources of phosphorus and nitrogen}

\section{Agriculture}

The main kinds of crops cultivated in the watershed and the area occupied by each one were determined from Agricultural Census database (INE, 1999). Data on quantities of $\mathrm{N}$ and $\mathrm{P}$ applied to crops, as well as on mean annual productivity of each crop, were obtained from PBHD (1998). The mean values concerning $\mathrm{N}$ or $\mathrm{P}$ removed from soil by each single species and the mean quantities of those nutrients contained in its residuals, which are returned to soil, are data mentioned in Ministry of Agriculture (Ministério da Agricultura, 1997). The $\mathrm{N}$ and $\mathrm{P}$ loads resulting from agricultural activity and potentially transferred every year into Azibo were determined by calculating the following balance adapted from PBHD (1998) for each crop:

$$
\mathrm{PL}=(\mathrm{A}-\mathrm{R}+\mathrm{L}) \times \mathrm{C}
$$

where: PL - potential loading (kg/year); A - quantity of $\mathrm{N}$ or $\mathrm{P}$ application ( $\mathrm{kg} / \mathrm{ha}$ per year per crop); $R-$ quantity of $\mathrm{N}$ or $\mathrm{P}$ removed from the soil $(\mathrm{kg} / \mathrm{ha}$ per year per crop). $R$ was obtained by multiplying mean productivity of each crop by the mean value of $\mathrm{N}$ or $\mathrm{P}$ removed from soil by each plant. Finally, this result was multiplied by crop's area; $L$ - quantity of $\mathrm{N}$ and $\mathrm{P}$ left in the soil ( $\mathrm{kg} / \mathrm{ha}$ per year pre crop residuals). $L$ was obtained by multiplying mean productivity of each crop by the mean value of $\mathrm{N}$ or $\mathrm{P}$ contained in the residuals. At the end, this result was multiplied by crop's area; $C$ - area of the crop in the catchment basin (ha).

\section{Livestock}

The numbers of cattle, sheep and goat grazing in the watershed were taken from the Agricultural Census database (INE, 1999). Annual amounts of $\mathrm{N}$ and $\mathrm{P}$ excreted by cattle were calculated by multiplying the mean annual quantity of $\mathrm{N}$ and $\mathrm{P}$ excreted by one animal (105 kg N and $35 \mathrm{~kg} P$ per year) by total number of animals grazing in the catchment basin. In the same way, the total amounts of $\mathrm{N}$ and $\mathrm{P}$ excreted by sheep and goat per year were obtained by multiplying the average quantity of $\mathrm{N}$ and $\mathrm{P}$ excreted per year by one animal (21 kg N and $9 \mathrm{~kg} \mathrm{P})$ by sheep and goat all together (Ministério da Agricultura (Ministry of Agriculture) 1997). As grazing in this region is extensive and consequently animals spend most of the day in pastures and meadows, in this paper it was assumed that livestock waste was not used in agricultural fields. Conversely, pig and poultry waste was not considered because those animals are kept in stocking and their waste can be used for fertilisation.

\section{Sewage}

Sewage from small villages located at Azibo catchment basin is discharged in the streams without a previous treatment. Loads originated from sewage were calculated according to coefficients (3285 g N and $1168 \mathrm{~g}$ P per person and year) mentioned in PBHD (1998).

\section{Bathing and angling}

Loads originated from those activities were calculated according to coefficients adapted from Szyper \& Goldyn (2002). Therefore, amounts of $\mathrm{N}$ and $\mathrm{P}$ originated from bathing were calculated by multiplying the load coefficient from one person $(1.0 \mathrm{~g} \mathrm{~N}$ and $0.046 \mathrm{~g} \mathrm{P}$ per day) by the mean number of summer days in the region (90) and the total number of people bathing in the reservoir. The load from anglers was estimated by multiplying their total number by the mean number of angling days per year (180) and by the mean amount 
Table 2. Physical factors recorded for S. Serrada and Azibo reservoirs. Minimum-maximum range, with mean and standard deviation in brackets are shown

\begin{tabular}{lll}
\hline S. Serrada & 2000 & 2001 \\
\hline Water temperature $\left({ }^{\circ} \mathrm{C}\right)$ & $1.46-21.39(12.51 / 6.59)$ & $2.70-20.19(12.90 / 6.46)$ \\
Dissolved oxygen $(\mathrm{mg} / \mathrm{l})$ & $7.38-12.42(8.55 / 1.45)$ & $6.20-10.72(8.55 / 1.49)$ \\
Conductivity $(\mu \mathrm{S} / \mathrm{cm})$ & $4-10(6.94 / 1.84)$ & $3-8(5.95 / 1.61)$ \\
Water transparency $(\mathrm{m})$ & $4.50-1.00(2.66 / 1.09)$ & $1-5(2.85 / 1.14)$ \\
$\mathrm{pH}$ & $5.77-6.56$ & $5.95-8.34$ \\
Water colour $(\mathrm{Pt}$ units) & $0.44-46.35(17.39 / 14.27)$ & $5.24-35.45(18.55 / 9.36)$ \\
Azibo & & \\
Temperature $\left({ }^{\circ} \mathrm{C}\right)$ & $5.58-24.7(16.52 / 6.13)$ & $8.06-23.83(17.16 / 5.73)$ \\
Dissolved oxygen $(\mathrm{mg} / \mathrm{l})$ & $7.54-11.53(9.09 / 1.06)$ & $7.21-10.78(8.99 / 1.33)$ \\
Conductivity $(\mu \mathrm{S} / \mathrm{cm})$ & $51-81(69.87 / 11.09)$ & $43-66(56.23 / 7.64)$ \\
Water transparency $(\mathrm{m})$ & $1.5-6.0(4.72 / 1.25)$ & $1.5-5.5(3.50 / 1.14)$ \\
$\mathrm{pH}$ & $6.71-8.05$ & $6.64-8.36$ \\
Water colour $(\mathrm{Pt}$ units $)$ & $0.0-9.02(2.82 / 3.02)$ & $0.0-21.81(6.21 / 5.66)$ \\
\hline
\end{tabular}

of $\mathrm{N}$ and $\mathrm{P}$ produced by angler per day (156 $\mathrm{g} \mathrm{N}$ and $28.8 \mathrm{~g} \mathrm{P})$.

\section{Results}

Maximum and minimum ranges, as well as mean and standard deviation values for water temperature, dissolved oxygen, conductivity, $\mathrm{pH}$ and water colour observed in S. Serrada are presented on Table 2. Trends in TP, SRP, N-NO 3 and CHL $a$ for S. Serrada in both years are shown in Figure 3. In 2000, TP concentrations ranged between 21.01 and $113.22 \mu \mathrm{g}$ $1^{-1}$, while in 2001 the variation was between 41.52 and $132.74 \mu \mathrm{g} \mathrm{l}^{-1}$. The highest values of TP were recorded together with the maximal values of precipitation and with the decrease of water levels occurring from July to October. Similar trends were observed for SRP. $\mathrm{N}-\mathrm{NO}_{3}$ concentrations varied between 0.3 and $8.0 \mathrm{mg} / \mathrm{l}$ in 2000 and between 0.1 and $17.8 \mathrm{mg} / \mathrm{l}$ in 2001 and followed a similar pattern to TP and SRP concentrations, except in summer 2001 . N-NH 4 concentrations were always very low and varied between 0 and $0.3 \mathrm{mg} / 1$ in 2000 , and were not detectable in

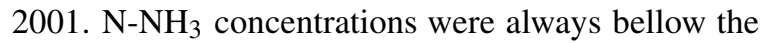
detection limits. CHL a concentrations varied between 0 and $7.97 \mu \mathrm{g} \mathrm{l}^{-1}$ in 2000 and between 0.1 and 10.45 $\mu \mathrm{g}^{-1}$ in 2001 . Trends in concentrations were similar in both years with a smaller peak in the beginning of spring and the highest one from the end of summer till the end of autumn.

Variation in water temperature, dissolved oxygen, conductivity, $\mathrm{pH}$ and water colour obtained in Azibo is shown on Table 2. TP, SRP, N-NO 3 and CHL $a$ recorded in Azibo are presented in Figure 4. TP concentrations ranged between 34.28 and $89.69 \mu \mathrm{g} \mathrm{l}^{-1}$ in 2000, while in 2001 those ranged between 41.70 and $102.84 \mu \mathrm{g}^{-1}$. During 2000 the highest values of TP concentrations were obtained from July to October, when direct influence of human activities were more intense. In 2001 the highest TP concentrations were recorded together with the maximal values of precipitation and again from July to October. SRP concentrations varied from 0 to $23.86 \mu \mathrm{g}^{-1}$ in 2000 and from 1.53 to $15.30 \mu \mathrm{g} \mathrm{l}^{-1}$ in 2001 , and followed a similar pattern to TP concentrations, except in summer 2001 when values varied little till the end of summer. $\mathrm{N}^{-\mathrm{NO}_{3}}$ varied from 0.5 to $14.80 \mathrm{mg} / \mathrm{l}$ in 2000 , while in 2001 ranged between 0.2 and $18.80 \mathrm{mg} / \mathrm{l}$ and showed similar trends to TP concentrations. However, in 2001 the largest increase in concentrations only oc-

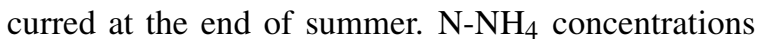
ranged between 0 and $0.3 \mathrm{mg} / 1$ in 2000 , whereas in 2001 concentrations were between 0 and $0.1 \mathrm{mg} / \mathrm{l}$. N$\mathrm{NH}_{3}$ concentrations were always bellow the detection limits. CHL $a$ concentrations ranged between 0 and $2.73 \mu \mathrm{g}^{-1}$ while in 2001 varied between 0.53 and $6.57 \mu \mathrm{g}^{-1}$. In both years chlorophyll concentrations peaked twice. In 2000 the peaks were observed from March to June and in autumn. In 2001 the first peak was obtained from January to March and the second one from September to December.

According to Carlson's Trophic State Index (the three components together) both reservoirs were classified as meso-eutrophic from winter to the beginning of summer and from this period onwards as eutrophic. In S. Serrada TSI (TP) varied between 48 and 72 in 2000 and between 58 and 75 in 2001. TSI (SD) ranged between 38 and 60 in 2000 and between 37 and 60 in 2001. TSI (CHL) varied between 14 and 51 in 2000 and between 8 and 54 in 2001. In Azibo TSI (TP) ranged between 55 and 69 in 2000 and between 58 and 71 in 2001. TSI (SD) varied between 34 and 54 in 2000 and in 2001 between 35 and 54 . TSI (CHL) ranged between 13 and 40 in 2000 and between 17 and 49 in 2001. Considering the separate components of the Index, according to the phosphorus component both reservoirs are classified as mesoto eutrophic, mostly eutrophic. However, it is important to consider, when regarding TSI (CHL), that phytoplankton communities, in both reservoirs, were dominated by species of small dimensions (less than $50 \mu \mathrm{m})$. Because of their small size, phytoplankton cells are edible to zooplankters and might be object 

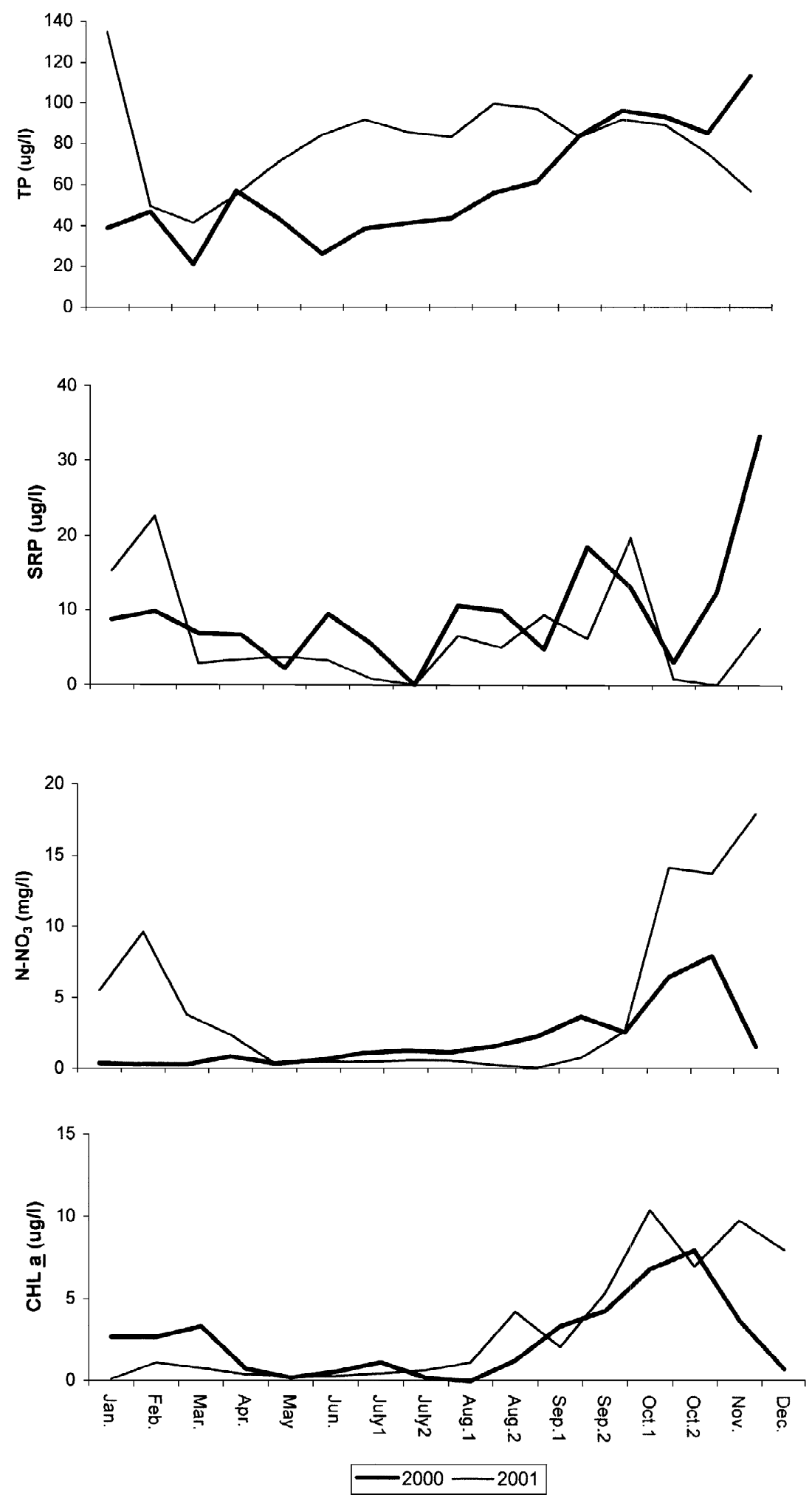

Fig. 3. Variation of TP, SRP, $\mathrm{N}^{-\mathrm{NO}_{3}}$ and $\mathrm{CHL} a$ concentrations in S. Serrada Reservoir for the period of study. 

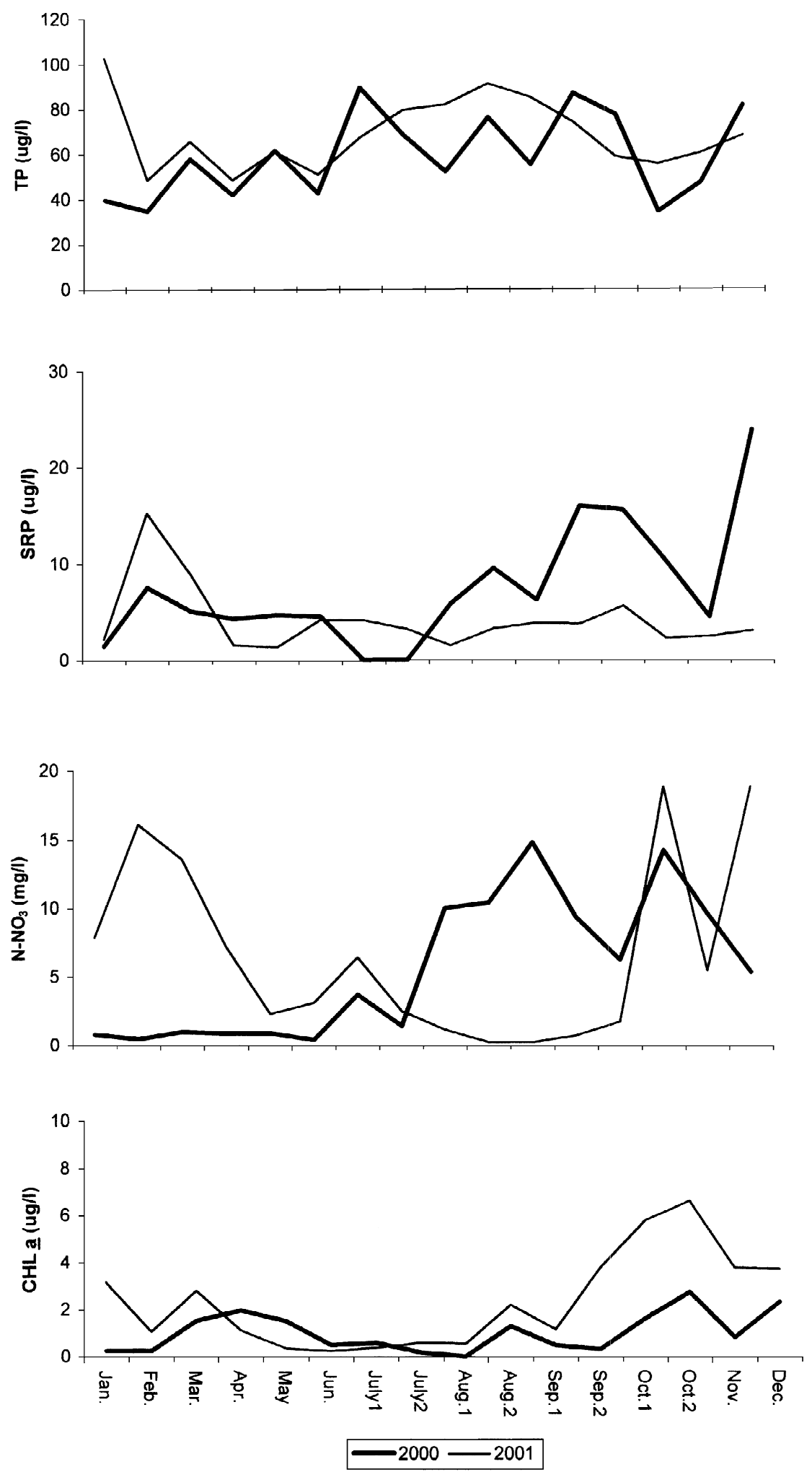

Fig. 4. Variation of TP, SRP, $\mathrm{N}-\mathrm{NO}_{3}$ and CHL $a$ concentrations in Azibo Reservoir for the period of study. 
of herbivory, thus be controlled by zooplankton. Nevertheless, eutrophication is, by definition, an increase in phytoplankton biomass, reflected on chlorophyll concentrations, which reinforces interpretation of the chlorophyll component of the index: Following that, it is most correct to consider both reservoirs as oligoto mesotrophic during the study period, instead of considering them as meso- to eutrophic.

The potential allochthonous sources of phosphorus and nitrogen are presented in Figure 5. In S. Serrada, grazing can contribute $30450 \mathrm{~kg}$ of $\mathrm{N}$ and $13050 \mathrm{~kg}$ of $\mathrm{P}$ per year. Wildfires can also contribute substantial loads. However, for this region there are no data allowing quantification of this source. In Azibo trophic state is possibly influenced by agriculture, grazing, sewage, as well as by angling and bathing. Agriculture can contribute $36394 \mathrm{~kg}$ of $\mathrm{N}$ and $49192 \mathrm{~kg}$ of $\mathrm{P}$ per year, grazing $172956 \mathrm{~kg}$ of $\mathrm{N}$ and $60786 \mathrm{~kg}$ of $\mathrm{P}$ per year and sewage $4927 \mathrm{~kg}$ of $\mathrm{N}$ and $1752 \mathrm{Kg}$ of $\mathrm{P}$ per year. Angling and bathing can contribute $28080 \mathrm{~kg}$ of $\mathrm{N}$ and $5184 \mathrm{~kg}$ of $\mathrm{P}$ and $900 \mathrm{~kg}$ of $\mathrm{N}$ and $41.5 \mathrm{~kg}$ of $\mathrm{P}$ per year, respectively.

Results of MDS are depicted on Figure 6. In this kind of diagram, sample to sample dissimilarity is represented by the distance between points. Thus, the gradation in the spread of the points indicates the existence of two groups: One formed by samples obtained at S. Serrada and one formed by those obtained at Azibo. This means that there is an inter-reservoirs variability related to some of the studied parameters. In fact, according to Kolmogorov-Smirnov test, nutrient and CHL a concentrations showed no significant differences between reservoirs in spite of differences in age, landscape occupation, water use and exposure to different degrees of disturbance. However, differences between reservoirs were found for conductivity $\left(D_{\mathrm{m}}=1 ; P<0.05\right)$, water temperature $\left(D_{\mathrm{m}}=\right.$ $0.364 ; P<0.05)$, pH $\left(D_{\mathrm{m}}=0.758 ; P<0.05\right)$, transparency $\left(D_{\mathrm{m}}=0.455 ; P<0.05\right)$ and water colour $\left(D_{\mathrm{m}}=0.643 ; P<0.05\right)$.

\section{Discussion}

The values of the studied water quality parameters were similar for both reservoirs in spite of different age, landscape occupation, water use patterns and exposure to different factors of disturbance. The observed differences in water temperature, conductivity and $\mathrm{pH}$ might be the result of the synergistic effect of reservoir altitude and geological zone. Age may
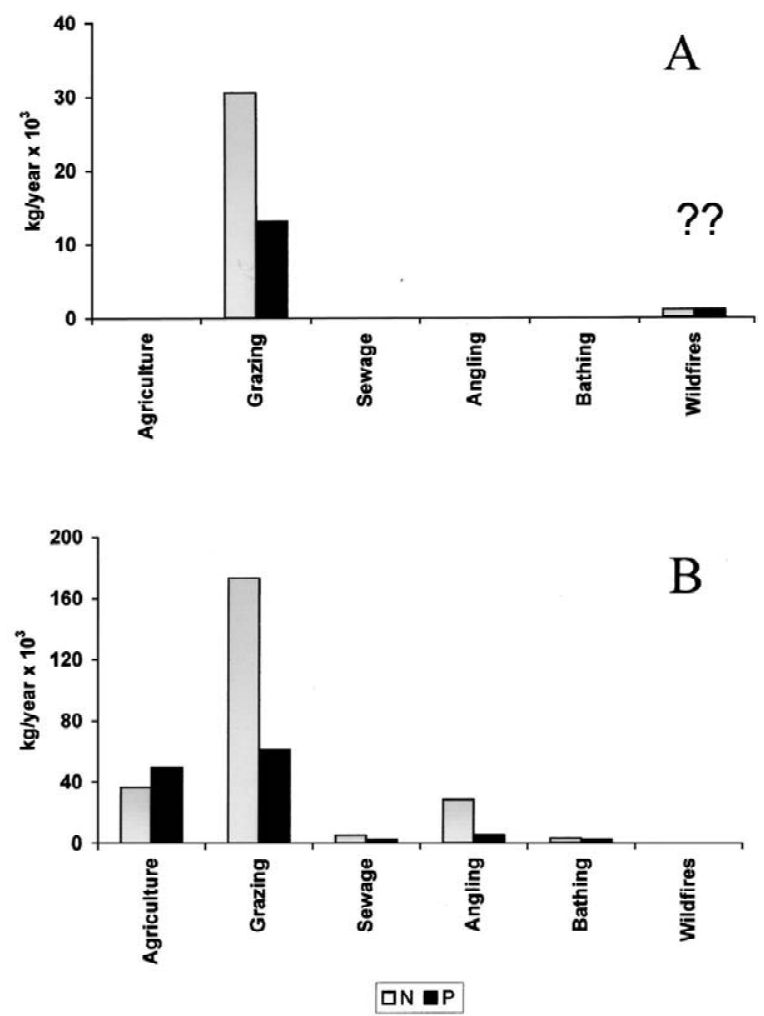

Fig. 5. Potential allochthonous sources of nitrogen and phosphorus to S. Serrada (A) and Azibo (B) reservoirs (?? means 'non quantified source').

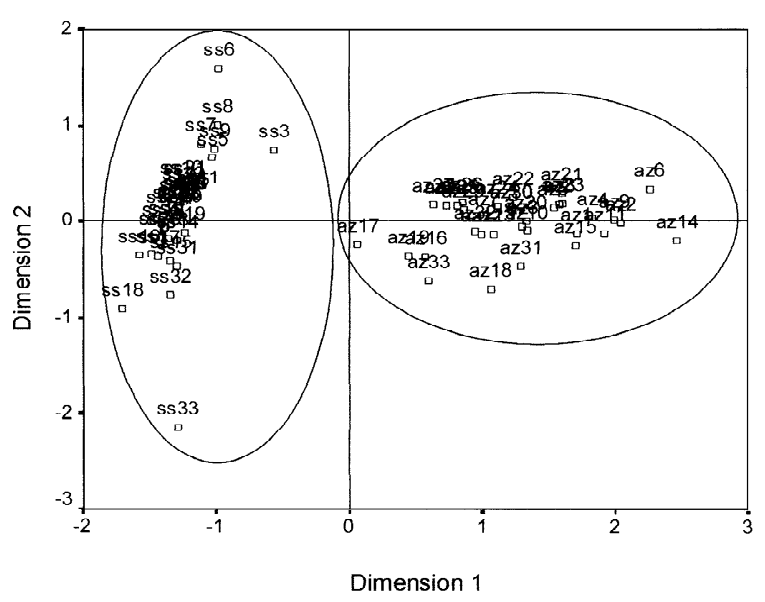

Fig. 6. Results of MDS ordination (ss - S. Serrada samples; az Azibo samples). 
be in the origin of the high water colour obtained for S. Serrada Reservoir. According to Cuthbert \& Giorgio (1992) humic compounds are products of plant decomposition and their concentration in the water can be measured by the determination of water colour. Thus, the obtained water colour values might indicate the existence of high amounts of products of terrestrial vegetation decomposition. In fact, the inundated area was previously a permanent meadow fertilised every year for potato crop production and the existing vegetation was not removed before inundation. Consequently, because of decomposition of the terrestrial vegetation, which can take several years, and because of the use of the land before creation of the reservoir, certainly large amounts of nutrients were and are being released to the water column. The almost total hypolimnetic oxygen depletion during stratification (Geraldes, unpublished data) may also be a sign of the presence of important quantities of organic matter in decomposition at the bottom of the reservoir. Similar results were obtained for other new reservoirs (Pinel-Alloul \& Méthot, 1984; Kimmel et al., 1988; Robarts et al., 1992). However, it looks like that factor does not play a preponderant role in the obtained results. Actually, S. Serrrada is a highly disturbed system if compared to other lakes located in similar geological and climate regions (e.g., Negro et al., 2000). There are two sorts of disturbance: one internal, because of water level fluctuation, and the other external, originating by the combined effect of grazing and fire. Furthermore, the areas of both reservoir and catchment are small. Thus, the intensity of use of water and grazing activity which could not have had a strong impact in systems surrounded by larger catchment areas, in this reservoir could have induced a severe reduction in water quality; the observed resuspension of bottom sediments and organic matter following water runoff input after the first rains, plus the turbulence generated by water level rising and the periodical exposure of littoral sediments to cycles of drying and wetting could explain the high phosphorus concentrations and consequently the found TSI (TP) and TSI (SD) values. This assumption is supported by the results obtained by Fabre (1988) and Watts (2000a,b) in reservoirs where water level fluctuation was accentuated as well. On the other hand, grazing is not only a source of nutrients but also the main cause of wild fires in this region, since those are induced by shepherds to obtain better graze. Actually, S. Serrada catchment is one of the areas with more fires per year in the Montesinho Natural Park (Rainha \& Cabral, 2001). There are no studies quantifying the nutrient inputs to this reservoir as a result of the erosive impact of rainfall on postburned soils. However, considering the high slope and the dominant soil type in this area, which, according to Agroconsultores \& Coba (1991) and to Ministério do Ambiente (1995), bear a high potential risk of erosion, then high rates of soil erosion and consequently high surface runoff are expected. In addition, some research developed in other regions has shown that the consequences of a fire can be the increase in trophic state and the subsequent decrease of water quality in the adjacent water bodies. Those effects are more accentuated in sloped areas and after intense precipitation events (Walsh et al., 1992; Shakesby et al., 1993; Townsend \& Douglas, 2000; Lange, 2001; Minshall et al., 2001).

In Azibo internal disturbance caused by water level fluctuation is minimal. Moreover, the areas of reservoir and catchment are larger than the corresponding ones for S. Serrada, landscape is patchy and fires are not frequent. However, other sources of disturbance such as agriculture, mainly the intensive cultures in reservoir shore, grazing and recreational activities, can be the cause for the obtained TSI (TP) values. Those were similar to the results obtained during the study performed in1987/1988 by Vasconcelos (1990). According to estimations of the potential allochthonous sources of nutrients, agriculture and grazing seemed to be the greatest sources of $\mathrm{N}$ and $\mathrm{P}$ in the Azibo catchment. The intensity of exportation of nutrients from those activities and from sewage seems to be highly seasonal; in the beginning of the wet season the nutrient concentrations in water runoff were higher than in the water runoff generated by end of season rains. The observed seasonality is corroborated by other authors (e.g., Johnes et al., 1996; Barbosa \& Hvitved-Jacobsen,1999; McGarrigle et al., 2000; Rybak, 2000). Geraldes (unpublished data) also noticed that TP concentrations in samples obtained at the terminus of one of Azibo's tributary streams were by the time of first water runoffs (November 2000/December 2000) $103 \mu \mathrm{g} \mathrm{l}^{-1}$, in February 2001 decreased to $76 \mu \mathrm{g} \mathrm{l}^{-1}$ and in March 2001 decreased again to $16 \mu \mathrm{g} \mathrm{l}^{-1}$. However, agricultural and grazing sources of nutrients are expected to decrease within few years, since most of the farmers are more than 50 years old nowadays (INE, 1999, 2001) and there is a considerable tendency for human desertification because of the low rentability of agricultural practices. Besides, the landscape in this catchment is very patchy and consequently there are numerous buffer 
areas such as woodlands, meadows and riparian vegetation that can minimise those potential sources of nutrients. Thus, intensive agriculture practices in the reservoir shore and recreational activities in summer are or might become in a near future the main nutrient sources to Azibo Reservoir. In fact, the values of nutrient concentrations obtained in summer can be related to those activities, which are more intensive in this period. Another possible source of pollutants that can also affect water quality in Azibo is the highway IP4. According to Barbosa \& Hvitved-Jacobsen (1999) the average concentration levels of $\mathrm{Pb}, \mathrm{Zn}$ and $\mathrm{Cu}$ in the IP4 highway runoff are 10.8, 172 and $10.7 \mu \mathrm{g} \mathrm{l}^{-1}$, respectively.

Considering the possible causes for the nutrient concentrations obtained in both reservoirs and the occurrence of a bloom of Anabaena sp. in Azibo during the study performed by Vasconcelos (1990), plus the dominance of this cyanobacterium in the phytoplankton community more recently at the end of summer 2001 (Geraldes, unpublished data), it can be concluded that there is a need for implementation of several measures to prevent water quality degradation. In S. Serrada the following measures should be taken: (1) managing shrub communities and providing information to shepherds in order to prevent frequent fires; (2) forbidding grazing on reservoir shore; (3) allowing vegetation growth at the shores of the reservoir; (4) providing information to population of Bragança to prevent water waste and, in doing so, avoid extreme water level fluctuations in the reservoir. For Azibo the following measures are suggested: (1) restriction of fertilisers, mainly in the intensive agricultural exploitations located at reservoir shore; (2) implementation of effective sewage treatment (at least secondary treatment) in small villages; (3) establishment of well defined areas for camping and other recreational activities; (4) assessment of the actual impact of the highway IP4 on water quality and, if necessary, implementation of infiltration ponds for pollutant retention (Barbosa \& Hvitved-Jacobsen, 1999); (5) implementation of environmental education projects for both residents and tourists.

Complementarily to the suggested measures, some research work should be performed. There is a lack of data concerning, e.g., soil nutrient retention capacity and erosion rates. Such data are fundamental to develop export coefficient models adapted to these areas, allowing the correct estimation of nutrient and pollutant inputs, and to make possible the development of correct management measures for these reservoirs and their watersheds. Regular programs of water quality monitoring should also be implemented.

\section{Conclusions}

The absence of industrial activity and the low rentability of agriculture are leading Trás-os-Montes region to human desertification. Thus, the implementation of new activities such as rural tourism and ecotourism could be economic alternative to local populations. Both S. Serrada and Azibo reservoirs, as well as their watersheds, have high potential for the development of activities such as boating, fishing, pedestrian walks, hunting, nature watching and rural tourism. In order to improve and maintain water quality on multiple uses perspective it is necessary to promote the sustainable development of the surroundings and of the catchment areas of both reservoirs. To achieve this goal, it is necessary to elaborate and promote management plans that specify what and where activities mentioned above can be developed without jeopardising natural and cultural values. However, their efficacy will depend on co-operation between municipalities, conservation authorities, researchers and local inhabitants.

\section{Acknowledgements}

This study was supported by Fundação para a Ciência e a Tecnologia, Portugal (Project Praxis $\mathrm{XXI} / \mathrm{C} / \mathrm{BIA} / 11012 / 98$ to MJB) and a doctoral fellowship awarded to AMG (4/5.3/PRODEP/2000) for the last part of the study. Assistance of A. Ribeiro, A. Teixeira and N. Marcos in field work is appreciated. Agroclima Lab from ESAB provided precipitation data. J. Sampaio gently supplied data on tourist and angler activity in Azibo Reservoir.

\section{References}

Agroconsultores \& Coba, 1991. Carta de Solos. Projecto de Desenvolvimento Rural Integrado de Trás-os-Montes. UTAD, Vila Real.

Barbosa A. E. \& T. Hvitved-Jacobsen 1999. Highway runoff and potential for removal of heavy metals in an infiltration pond in Portugal. Sci. Total Environ. 235: 151-159.

Carlson, R. E., 1977. A trophic state index for lakes. Limnol. Oceanogr. 22(2): 361-369.

Cuthbert, I. D. \& P. Giorgio, 1992. Towards a standard method of measuring color in freshwater. Limnol. Oceanogr. 37(6): 13191326. 
Fabre, A., 1988. Experimental studies on some factors influencing phosphorus solubilization in connexion with the drawdown of a reservoir. Hydrobiologia 159: 153-158.

Hallisey, R., M. L. McGarrigle \& K. Donnelly, 2001. The relationship between in-stream total phosphorus and the characteristics of the surrounding catchment, Rappa River catchment, Co. Mayo, Ireland. Verh. int. Ver. Limnol. 27: 3556-3560.

Harper, D., 1992. Eutrophication of Freshwaters — Principles, problems and restoration. Chapman \& Hall, London.

INE, 1999. Censos da Agricultura, 1999. Instituto Nacional de Estatística.

INE, 2001. Censos da População 2001. Instituto Nacional de Estatística.

Johnes, P., B. Moss \& G. Phillips 1996. The determination of total nitrogen and total phosphorus concentrations in freshwater from land use, stock headage and population data: Testing of a model for use in conservation and water quality management. Freshwat. Biol. 36: 451-473.

Kimmel, B. L. D. M. Soballe, S. M. Adams, A. V. Palumbo, C. J. Ford \& M. S. Bevelhimmer, 1988. Inter-reservoir interactions: Effects of a new reservoir on organic matter production and processing in a multiple-impoundment series. Verh. int. Ver. Limnol. 23: 985-994.

Lange, R. W., 2001. A methodology for estimating detectable change in water quality due to prescribed fire in north Colorado. Master Degree Thesis. Colorado State University. Fort Collins, Colorado.

McGarrigle, M. L., R. Hallisey, K. Donnelly \& L. Kilmartin, 2000. Trends in phosphorus loading to Lough Conn, Co. Mayo, Ireland. Verh. int. Ver. Limnol. 27: 2642-2647.

Ministério da Agricultura, 1997. Código de boas práticas agrícolas para a protecção da água contra a poluição com nitratos de origem agrícola. Ministério da Agricultura do Desenvolvimento Rural e das Pescas.

Ministério do Ambiente, 1995. Plano nacional da política de ambiente. Ministério do Ambiente e Recursos Naturais.

Minshall, G. W., J. T. Brock , D. A. Andrews \& C. T. Robinson, 2001. Water quality and biotic responses of five central Idaho (USA) streams during the first year following the Mortar Creek fire. Int. J. Wildland Fire 10: 185-199.

Murphy, J. \& J. P. Riley, 1962. A modified single solution method for the determination of phosphate in natural waters. Analytica chim. Acta 27: 31-36.

Negro, A. I., C. De Hoyos, C. \& J. C. Vega, 2000. Phytoplankton structure and dynamics in Lake Sanabria and Valparaíso reservoir (NW Spain). Hydrobiologia 424: 25-37.
PBHD, 1998. Plano de Bacia Hidrográfica do Douro. $1^{\text {a }}$ Fase- Análise e diagnóstico da situação actual. Anexo 6C- Poluição Difusa. Instituto da Água.

Pinel-Alloul, B. \& G. Méthot 1984. Analyse multidimensionnelle de l'evolution du zooplancton durant la mise en eau de trois reservoirs du Nord du Québec, Canada. Verh. int. Ver. Limnol. 22: $1444-1455$.

Rainha, M. \& P. Cabral, 2001. Incêndios ocorridos na área do Parque Natural de Montesinho (1994-2001). Parque Natural de Montesinho - Internal Report.

Robarts, R. D., T. Zohary, A. C. Jarvis, C. M. Pais-Madeira, L. M. Sephton \& S. Combrink, 1992. Phytoplankton and zooplankton population dynamics and production of a recently formed African reservoir. Hydrobiologia 237: 47-60.

Rybak, J., 2000. Long-term and seasonal dynamics of nutrient export rates from lake watersheds of diversified land cover pattern. Verh. int. Ver. Limnol. 27: 3132-3136.

Shakesby, R. A, C. O. A. Coelho, A. D. Ferreira, J. P. Terry \& R. P. D. Walsh, 1993. Wildfire impacts on soil erosion and hydrology in wet mediterranean forest, Portugal. Int. J. Wildland Fire 3(2): 95-110.

Sokal, R. R. \& F. J. Rohlf, 1981. Biometry. W.H. Freeman \& Co., San Francisco, CA.

Szyper, H. \& R. Gołdyn, 2002. Role of catchment area in the transport of nutrients to lakes in the Wielkopolska National Park in Poland. Lakes Reservoirs: Res. Manage. 7: 25-33.

Ter Braak, C. J. F., 1995. Ordination. In Jongman, R. H. G., C. J. F. Ter Braak \& O. F. R. van Tongeren (eds), Data Analysis in Community and Landscape Ecology. Cambrige University Press, Cambridge: 91-173.

Townsend, S. \& M. Douglas, 2000. Fire, erosion and water quality of streams. Caring Catchments 6: 1 .

Vasconcelos, V. M., 1990. First approach to the limnology of Azibo Reservoir (Portugal). Publ. Inst. Zool. 'Dr A. Nobre' 218: 1-21.

Watts, C. J., 2000a. The effect of organic matter on sedimentary phosphorus release in an Australian reservoir. Hydrobiologia 431: $13-25$.

Watts, C. J., 2000b. Seasonal phosphorus release from exposed, re-inundated littoral sediments of two Australian reservoirs. Hydrobiologia 431: 27-39.

Walsh, R. P. D., C. O. A. Coelho, R. A. Shakesby \& J. P. Terry, 1992. Effects of land use management practices and fire on soil erosion and water quality in Agueda Basin, Portugal. GEOÖKO plus 3: 15-36.

Wetzel, R. G., 2001. Limnology - Lake and river ecosystems. 3rd Edition. Academic Press, New York. 